\title{
At Home in Public: Intimacy and Belonging among Filipina and Indonesian Migrant Domestic Workers in Hong Kong in Ani Ema Susanti's Effort for Love (2008) and Moira Zoitl's Exchange Square (2007)
}

Carlos M. Piocos III*

This article discusses how Filipina and Indonesian domestic workers in Hong Kong claim and transform transnational sites as portrayed in Ani Ema Susanti's 2008 short documentary film Mengusahakan Cinta [Effort for Love] and Moira Zoitl's documentary video series Exchange Square (2007). The films depict how Indonesian and Filipina domestic workers negotiate precarious working and living conditions by deploying forms of intimacy, through their social practices and alternative sexualities, that enable them to gain agency in finding their own community and sense of belonging. This article argues that while their relationship to both private and public spaces in Hong Kong is transformed, these migrant women also actively transgress the borders of private and public spheres and personal and political realms.

Keywords: migrant domestic workers, public spaces, documentary, belonging, intimacy

On Sundays, two of the busiest shopping and business districts of Hong Kong, Central District and Causeway Bay, transform into festive sites where Filipina and Indonesian women congregate, relax, and socialize with their fellow domestic workers. Filipinas huddle in groups on picnic blankets made from corrugated carton boards, in front of boutique shops, government offices, and banks, near bus stops, or over the long walkways connecting posh shopping malls and hotels. They occupy most of the Central District, Statue Square, Chater Gardens, the closed-off Chater Road, and adjacent streets. Three stops away from Central MTR station, Indonesian women dominate the west end area of the huge Victoria Park complex in Causeway Bay where they, like their Filipina counterparts, meet and join their friends to exchange food and stories throughout the day. The ritual gathering of these foreign domestic workers (FDWs) during their days off, which started during the early 1980s for Filipinas and in the mid-1990s for Indonesian 
women, has already become a staple sight that adds to the already vibrant and diverse Hong Kong cosmopolis (Constable, 1997, p. viii).

Hong Kong is among the top five destination cities of migrant workers from the Philippines and Indonesia (International Organization for Migration, 2010). As of 2013, there are around 321,000 foreign domestic helpers in Hong Kong, half of which are Filipino women while $48 \%$ are Indonesian women (Census and Statistics Department HK, 2014). Together with a few hundred Thais, Nepalese, and Cambodians, FDWs comprise around 5\% of Hong Kong's population (Census and Statistics Department $\mathrm{HK}, 2014)$. And as they increasingly become ubiquitous, they also become necessary economic supplements to both their receiving state and their homeland.

Foreign helpers fill in Hong Kong's care gap by providing household, child, and elderly care services. Their presence in households frees 110,000 mothers from their domestic obligation and allows them to participate in the city-state's economic activities (Carvalho, 2019). At the same time, FDWs contribute significantly to their respective homeland's economic vitality such that their own governments consider them heroes. In the official state rhetoric and even in mass media and popular culture, Indonesian migrant workers are called pahlawan devisa or foreign exchange heroes (Nurchayati, 2010) while overseas Filipino workers are labelled bagong bayani or modernday heroes (de Guzman, 2003).

Filipina and Indonesian domestic workers do not just mitigate their respective country's problem of domestic unemployment but also help buoy their home countries' national reserves through their foreign exchange remittances. In 2012 alone, for example, the dollar remittances of Filipino migrants amounted to $\$ 21.39$ billion, which is more than 10 percent of the country's GDP (Remo, 2013), while Indonesian migrants' remittances registered at $\$ 9.2$ billion or more than one percent of their GDP for the same year (Anjaiah, 2013). Their economic contribution is also felt by their host city-state as recent findings show that they contributed $\$ 12.6$ billion to Hong Kong's economy in 2018, which is around 3.6\% of the city's GDP (Carvalho, 2019).

Even though they are seen as necessary supplement to the economic prosperity of both their home and host countries, a significant number of these FDWs documented by various NGOs are subjected to exploitative conditions such as working for more than a hundred hours per week, some without weekly or monthly days off, for less than $\$ 500$ per month (Amnesty International, 2013). Their precarious working environment is made worse by mandatory live-in arrangement that results in 'flexible' working hours, overwork, and various types of abuse (Mission for Migrant Workers, 2013). 
This arrangement blurs not just their work-home life boundaries but also the spatial division which separates their private and public selves. This is why the "spectacle" of migrant women hanging out in public spaces such as parks, streets, and storefronts in Hong Kong during Sundays is a consequence of their vulnerable working and living conditions and an important weekly ritual that allows them not just to relax and rejuvenate from their heavy workweek but to forge social and intimate relationships not usually available in the private spaces of their employers' households.

The interesting transformation of public and private spaces in Hong Kong and how Southeast Asian migrant domestic workers navigate these two realms are depicted in Ani Ema Susanti's (2008) short documentary film Effortfor Love [Mengusahakan Cinta] and Moira Zoitl's (2007) documentary video series Exchange Square. Susanti's film focuses on two Indonesian migrant women who try to make their romantic relationships work despite the challenges of being foreigners and guest workers in the city-state. Zoitl's video series, on the other hand, portrays the various activities of Filipina migrant workers inside their employers' households and in Hong Kong's public places, from running errands to joining protest rallies. These two films reveal how FDWs traverse Hong Kong's public and private spheres. The films also problematize the various consequences of their subjects' social practices as they try to lay claim to belonging in the city-state amid exclusionary policies and discourses.

Several studies have already examined the strategies of how migrant women navigate public spaces in their host city-states (Constable, 1997; Yeoh \& Huang, 1998), including the various practices and rituals that they perform in public that transform these spaces (Lai, 2010; Law, 2001). Scholars have also looked into how public and private spheres are transformed by how migrant women practice their sexuality and intimacy to cope with isolation and alienation inside their employers' households (Sim, 2009; Ueno, 2013). Finally, there are several studies that demonstrate how public spaces become contested sites where Filipina and Indonesian domestic workers exhibit some form of 'minor cosmopolitanism' through off-day practices such as participating in political demonstrations, that radically forward their claims of belongingness in the city (Constable, 2010; Law, 2002a, 2002b; Yeoh, 2004).

In this article, however, I examine not just how Effort for Love and Exchange Square depict these migrant women's practices in their host cities. Aitken and Zonn (2004) claimed that "the very heart of the search for our sense of place and sense in the world is constituted by the practice of looking, and in effect, a study of images" (p. 7). This is also how these two visual narratives produce imaginaries of space where subaltern migrant women 
bodies perform transgressions of private/public and national/transnational divisions. Through textual analysis of these two films, I will show how documentary cinema interrogates as well as intervenes with "ethnographic data" by producing and circulating images of migrant women's everyday practices and intimate stories that complicate issues of social exclusion and belonging in receiving states. Alev Cinar and Thomas Bender (2007) argued that "the city is located and continually reproduced through the orienting acts of imagination, acts grounded in material space and social practice" (p. xii). Thus, this paper attempts to look into the ways these films also produce images of the everyday lived experiences of diasporic subjects that forward alternative imaginaries of belonging in Hong Kong.

In this paper, I will first briefly talk about how space is a contested arena in Hong Kong politics and how this affects the lives of migrant women. Second, I will discuss how representations of space in documentary cinema become an important site for such contestation. My discussion then dovetails into how these two contemporary films document and reimagine the city-state's public spaces, anchoring them on the particularities of lived experiences of Filipina and Indonesian domestic workers. Last, I will discuss how these films' production and circulation of images and imaginaries of Filipina and Indonesian migrant women' social practices 'politicize' both private and public spaces in Hong Kong.

\section{Spaces of Contestation}

Space is a very scarce and expensive resource in Hong Kong. Due to economic hyperdevelopment throughout the past decades, realty prices in the citystate continue to spike, with commercialization eating up residential spaces and heritage sites (Cheung, 2017). This makes space not just an economic but also a politically-charged issue as residents fight to maintain their own place amid the swift transformation (Sahin, 2017).

The fight for one's own space is felt much more intensely by foreign workers. As findings of NGOs have pointed out, many migrant domestic workers are suffering from improper accommodation, living in households without privacy and sufficient provision for rest and relaxation. Some of them are sleeping with their wards, or worse, in bathrooms, kitchens, living rooms, and even in hallways outside their employers' units (Hincks, 2017). NGO campaigns for live-out options or even just decent accommodation inside employers' households for foreign helpers have been an uphill struggle (Siu \& Lau, 2018). Calling for "proper" living arrangement for guest workers is against the interest of the rest of the citizens and residents who are themselves living in dismally narrow spaces at such bloated cost (Kwok, 2019). Additionally, the idea of guest workers renting their own place poses 
an even bigger threat for Hong Kong locals as they would potentially drive up the prices for the already scarce housing resources (Siu, 2018). Thus, due to this lack of private spaces, public spaces of Hong Kong have become sites for refuge for Filipino and Indonesian migrant workers, who build their home away from home during their days off.

For many locals and tourists, finding hundreds of Filipino and Indonesian women on Sundays in Central and Causeway Bay signify Hong Kong's benevolence toward its foreign workers. Filipino and Indonesian women, who for most of the week are at their employers' beck and call, doing household chores, attending to their wards, and taking care of other household needs, seem to have been granted a time and a place by the city-state to go out of their workplaces to rest, mingle with friends, and do things that they will not normally do under their bosses' supervision. This is partially true: the Hong Kong government made weekly rest days for foreign helpers compulsory decades earlier than other Asian host states like Singapore, Taiwan, and Malaysia, though just like any resident in Hong Kong, they have to fight for a space for their days off. A Hong Kong resident's right to freely assemble and participate in organizations and public demonstrations is also being enjoyed by its guest workers-a right they would not have had in other receiving states in the Middle East, and Southeast and East Asia. Nicole Constable (1997) cited the Battle for Chater Road Case in the autumn of 1992 that started with Hong Kong Land's proposal to keep Filipina women from "taking over" the areas of their businesses and putting them somewhere "out of sight," like underground car parks or amusement parks (p. 5). This proposition resulted in a heated public debate, where opinions ranged from dismay over how foreigners were turning the posh areas into "slums," to disdain over the property owner's segregationist and discriminatory tendencies towards foreign maids (p. 7). Amid these raging public exchange in newspaper columns and op-eds, Filipina domestic workers expressed their resistance in more embodied ways, reiterating their claims through mundane social practices: "By laughing, talking and eating en masse, [they] demanded to be seen and refused to be moved" (p. 8). They claimed public spaces in Chater Road just by congregating there every Sunday. This ritualized practice of gathering later on compelled Hong Kong to not only permit such an act but also close off traffic in some streets and cordon off particular areas of its parks to give way to these migrant women. Thus, if at present this gathering has already become an accepted part of Hong Kong's weekly urban scenery, it is in no small part thanks to many FDWs' embodied articulations on the limits of Hong Kong hospitality.

This makes their Sunday gathering a way to not only occupy Hong Kong's 
public spaces but also intervene in the city-state's public spheres-a social practice which Law (2001) described as "a form of embodied experience that both 'takes place' and is 'produced"' (p. 266). Seen in this way, Filipino and Indonesian women's use of Hong Kong's urban landscapes is then not only a consequence of their material and social conditions but more importantly a response to these same conditions. It has altered the function of their host state's urban landscapes and has laid bare how inclusive their host is.

As the FDWs struggle to claim their own space in public, they are also demanded to answer for their public behavior by their home country, which they are expected to represent. When Indonesian lawmakers visited Hong Kong in 2006, for example, they were shocked to witness the "casual lifestyles" Indonesian migrant women were flagrantly displaying at Victoria Park. As one consul exclaimed: "If you go to Victoria Park on Sunday, you can see that some fellow Indonesians can be quite intimate. Some were turning to other women for comfort. Others were developing casual relationships with men from other races.... There was a worry that it would reflect poorly on the country's reputation among foreigners" (Ma, 2006). This compelled the Indonesian consulate in Hong Kong to conduct a five-hour briefing for their domestic workers about matters of morality and the wrongness of their public displays of intimacy (Bok, 2013). This kind of response reveals the anxieties of their homeland over the kind of lives they are leading miles away from their country. But it fails to recognize that these kinds of relationships are ways by which migrant women negotiate their daily experience of alienation and marginalization in Hong Kong. For one, these intimate ties complicate their designations as mere household workers in host state, and reassert their capacity for intimacy-for care, love, or support-outside the regimes of paid intimate labor. For another, these bonds are part of the foundation on which vibrant migrant communities are built. Finally, and more importantly, these are transgressive acts that not only counter ideological prescriptions on how a "proper Indonesian woman" should behave abroad but also create new imaginaries of how they stake their claims in a foreign city through their sexuality.

\section{Documenting Public Spaces}

The struggles of finding one's own place in Hong Kong are documented and portrayed in Susanti and Zoitl's respective documentaries. Susanti's (2008) Effort for Love depicts how Indonesian migrant women's display of lesbian intimacy in Victoria Park produces counter-images of sexuality and serves as a means to reclaim their own bodies and claim their place in Hong Kong. Zoitl's (2007) Exchange Square, on the other hand, illustrates how Filipina women's embodied social practices, embedded in their ritualized day off 
every Sunday, do not just reshape and transform Central District but also generate new imaginaries of community that are crucial to their sense of belonging in transnational spaces.

Susanti's Effort for Love is part of the Indonesian omnibus Pertaruhan [At Stake], which is about women's sexuality. Produced by Indonesian filmmaker and feminist Nia Dinata, Pertaruhan (2008) includes four documentary shorts that tackle controversial themes of "overseas lesbian communities, inadequate health care for women, female circumcision, AIDS, and illegal prostitution" (Rony, 2012, p. 160), making it a clear target for state and public criticism in Indonesia, where public representations of women's sexuality and reproductive rights are still taboo. Susanti's particular short documentary centers around two Indonesian domestic workers in Hong Kong, Ruwati and Riantini (Rian for short), and their daily effort to maintain their romantic relationships back home and abroad. Ruwati maintains a long-distance relationship with a prospective husband in Indonesia while Rian, a divorcee and a single mother, practices samesex relationship with a fellow Indonesian migrant. Informed by her own experiences as a former domestic worker in Hong Kong, Susanti adeptly navigates the familiar spaces of the city-state in exploring her subjects' intimate stories and captures how they publicly negotiate intimacy.

Zoitl's documentary video series Exchange Square is part of her long term project spanning 2002 to 2011, that archives the various everyday experiences of South and Southeast Asian migrant women at Exchange Square, the complex of buildings surrounding Hong Kong Stock Exchange. It is composed of nine short clips approximately 10 minutes each and is part of a larger art project that includes a publication of photography book and an installation art exhibit. The series follows Ma. Theresa Hamto's life as a Filipina domestic helper on weekdays and an organizer at Central with fellow migrant women activists during her days off.

While these two film projects may seem different, it is important to note how they both present Hong Kong's public spaces in relation to their subjects. According to Judith Pernin (2010), space itself can be a protagonist in cinema as places do not just serve as grounds for narrative but also shape stories by providing the main characters conflicts and opportunities for movement and mobility (p. 26). In studying these two film projects then, it is important to understand how the two filmmakers employ documentary cinema in portraying space.

Both Effort for Love (Susanti, 2008) and Exchange Square (Zoitl, 2007) locate the spaces that their subjects traverse, from the private residences of their employers to the public parks, and depict the social practices that emerge out of the hospitality that Hong Kong extends to them. In Effort 
for Love (Zoitl, 2007), public spaces become places where intimacy can be professed. Ruwati is only able to make long distance calls at Victoria Park to her fiancé in Indonesia during her day off, while Rian takes advantage of her time walking her ageing ward in public to visit her girlfriend, another FDW. Viewers also get to witness Rian and her girlfriend's intimate moments while riding trains, going on a junket trip by the harbour, eating inside an Indonesian café, or singing videoke inside Abadi Store, a place where they also hold lesbian "wedding ceremonies." Causeway Bay in this film is not the usual wide-angle panoramic shots of bustling commerce and shopping. It takes on a different character as the audience gets to encounter contesting images of Indonesian womanhood and sexuality as coping mechanisms to alienation.

Space takes a much more political dimension in Exchange Square (Zoitl, 2007) as it exposes how Filipina domestic workers become cultural workers, case workers, organizers, and activists once they have set foot on Central District during their days off. In the documentary, Central District, usually portrayed in films as a financial district with looming skyscrapers, becomes a place where migrants congregate, perform poetry readings, and participate in protest demonstrations to assert their place in Hong Kong. Viewers witness alternative migrant communities and solidarities in scenes shots in Bethune House, a halfway house for distressed migrant women, and in Mission for Migrant Filipino Workers' office, a nonprofit organization that helps migrant women through counselling and welfare services.

Domitilla Olivieri (2016) explained the importance of space in documentary filmmaking in "enabling encounters with the other subjectivities" (p. 137), particularly of migrant subjectivities. Exploring space in documentary films, she said, "addresses the everyday experiences of inclusion and exclusion for subjects that often fall out of the spotlight of media or mainstream cinema" as it shows the "experience of feeling 'at home' (or not) which is not as much about a physical space as it is about a sense of familiarity; a sense of daily belonging" (p. 137). Analyzing Susanti and Zoitl's documentary films, I argue along those same lines: Filipina and Indonesian domestic workers generate a sense of "affective proximity," whereby representations of their social practices produce an alternative imagination of belonging in Hong Kong. Space in the films becomes a place "where 'strangers,' 'others' and their experiences of and from elsewhere are and were, always already here, part of the very fabric" of the city-state (p. 137).

In her work, Olivieri (2016) also focused on the techniques of observational cinema that can be seen in documentary films on migrants: "the intimate camera gaze" and "the focus on the everyday and the 
uneventful" (p. 138). In my close reading of the two films, I will demonstrate how these two techniques allow for a production of an alternative imaginary of cosmopolitan belongingness.

\section{Under the Public's Eyes}

Effort for Love (Susanti, 2008) uses a variety of shots to create a sense of familiarity and intimacy between the audience and the two subjects, Ruwati and Rian. These shots comprise Susanti's deployment of intimate camera gaze, which allows viewers to fully take in characters as they move through private and public spaces in the city-state and as they talk about their own experiences of intimacy.

Susanti employs close-up shots of the two characters talking about their daily life in Hong Kong, with their talking heads spilling over as voiceover of Ruwati and Rian's movements in the city, framed in both long takes and over-the shoulder shots. Through these scenes, the audience becomes familiar with the protagonists' struggles of being a foreigner and a woman looking for the promise of love.

The 40-year old college-educated Ruwati is framed as a "proper" woman abroad: both a devout Muslim and a good Indonesian citizen. She is a good worker, as seen in a close-range shot of her putting a baby to sleep while her employers are busy with their home-based business. The camera, with over-the-shoulder shots, follows her around when she goes to the market to do some errands. The audience hears her voice-over talking about how she spends her free time as a volunteer at the Indonesian Consulate in Hong Kong, teaching traditional religious dances to her fellow migrant workers, and how dutifully she follows her faith in Hong Kong. These scenes are interspersed with short clips of her training a group of tenaga kerja wanita (migrant domestic workers) in colourful krudung [veil] and a long-shot of hundreds of women in pure-white krudung bowing to pray during Id'l Fit'r at Causeway Bay.

In close-up interviews, however, Ruwati shares the growing tension with her fiancé back home. She reveals that she needs to have surgery for a uterine tumor-the camera pans a physician's monitor showing the word "hysteroscopy" during one of her consultations. But a uterine surgery goes against her moral stance that "only [her] future husband will see [her] vagina." And when she tells her fiancé that she is going through with the procedure, conflict ensues, as shown in the scenes where the camera is trailing Ruwati, and the audience sees her either arguing with him over the phone call or walking, distraught, around Causeway Bay because he rejected her calls. She only gets to convince her fiancé that the operation is necessary when she returns to Indonesia and seeks a second opinion from a local doctor. 
Ruwati's struggle to be the perfect wife-to-be typifies what Fatimah Toby Rony (2012) claimed as the "distillation of Suharto's regime's successful idealization of Kartini" (p. 164) or Indonesia's New Order model of womanhood that confounded Islam religiosity with nation-building agenda. Virginity in Ruwati's transnational context, visually marked by the protagonist in white krudung, covers a range of complex meanings on being a proper woman abroad that conflates civic duty with spirituality, which comes into play against normative biomedical and reproductive right issues. What is interesting in the film, however, is how Ruwati tries to mediate her own conservative viewpoints with modernist ideas on reproductive health that she picked up while working in Hong Kong. The intimate camera gaze is able to document this complex negotiation, and the audience gets to witness the various shifts in Ruwati's emotions-from frustration to desperation, to determination and relief. While not completely agreeing, she realizes that her moralistic assumptions on virginity can endanger her health. At the same time, she realizes that going through the procedure potentially jeopardizes her prospective marriage. This is why her attempt to persuade her fiancé is her way of fighting for her right to reproductive health and survival.

The second story in Effort (Susanti, 2008) is equally interesting as it focuses on Riantini or Rian. Deploying the same intimate camera techniques of close-up and over-the-shoulder shots, the director lets viewers follow Rian's daily life in Hong Kong. Like Ruwati, she ends up with a good employer, as seen in the long takes of her and her ageing ward walking around in the neighborhood and in the close-up shots of their hands clasped together during their walks. In the interviews, viewers learn that Rian is a divorcee and her ex-husband left her with a daughter back in her Indonesian village. In one scene, we see her writing a dedication on the shoebox she is going to send to her daughter back home. Rian, like Ruwati, is a good woman in the sense that she follows the script of the "good mother." But she also transgresses this role when she admits that she likes women ("Aku suka cewek," she says). The audience follows Rian's romantic affair with a fellow tenaga kerja wanita: we see her visiting her girlfriend while walking her ageing ward around their neighborhood, and during her days off, we see the lesbian couple teasing each other while eating in a noodle shop and cuddling in Victoria Park. The intensity of their relationship is summarized in Susanti's recreation of a karaoke video showing the couple kissing, offering flowers to each other, holding hands by the harbor, and strolling romantically in Hong Kong's streets while Rian is singing a love song. The intimate camera gaze that composes this montage of unbridled romanticism and sentimentality transforms Hong Kong as a space for transgressive 
intimacy. Feng-Mei Heberer (2017) read this karaoke segment as a narrative tool that reimagines Hong Kong's familiar imposing image of globalization and hyper-capitalism into an affective landscape for alternative intimacy:

Rather than telling us about the intimacy between Rian and her partner from a sober distance, then, the documentary shows itself overtaken by and being told through the affect of sentimentality that defines the protagonists' intimate performance ... It emerges as a narrative tool that inscribes an unrecognized social world into the hypervisible city of Hong Kong, itself a place defined by the tumultuous conjuncture of colonial histories, the intersecting forces of globalization and capitalism, and the pressure of a Chinese authoritarian state. (p. 440)

Amy Sim (2009), in her ethnography of Indonesian women's practice of sexuality in Hong Kong, explained how forging same-sex relationships is one way Indonesian women negotiate their ideas of intimacies in their largely alienated and marginalized positions in transnational households. Practicing homosexuality is perceived to be much more tenable among them, despite it being taboo in their home country. Because many of them either were abused in their past heterosexual relationships back home like Rian or feel more vulnerable entering a heterosexual relationship overseas for fear of unwanted pregnancy, which may cause termination to their jobs and repatriation, Indonesian migrant women prefer to either assume the masculine role of sentul [butch] or engage with another female migrant as kantil [femme] to ward off foreign men who can either abuse or impregnate them (p. 17). Rian takes on the role of sentul when she sports a short haircut, wears a baseball cap, dresses up in oversized shirts and jeans, and acts cocky in the streets, while her girlfriend is seen as diminutive kantil, "so calm and natural, so soft spoken and innocent but mature in her ways," according to Rian. These types of affairs, for Sim, "become not just a mark of modernity among them but a safety valve for their needs and emotions in unstable and unsafe spaces of migration" (p. 33). As such, forming this kind of intimacy in public can be liberating, helping FDWs gain a relative level of freedom and security in their precarious place as live-in maids.

While it may seem that "lesbi" Indonesian migrant women follow a Western model of queer sexuality, there are nuances in their practice of lesbian intimacy. Just like the term "virgin" in Ruwati's case, "lesbian" is a contested term in the context of Indonesian women abroad. According to Rony (2012), "gay and lesbian communities in Indonesia do not just adopt 
the Western ideas of sexuality wholesale, but 'dub' them and make them their own" (p. 166) through practices specific to their contexts. Rian, for example, never sees any contradictions in her roles as a dutiful mother to her daughter back home and gushy tomboy to her girlfriend abroad. In separate scenes, the audience get to see her professing her love to her daughter and to her girlfriend in the letters that she writes for both. However, she also recognizes that her intimate relationship is only momentary and can only exist in Hong Kong's public spaces. In one of the scenes in the documentary, she describes the bond she and her girlfriend maintains: "We made a pact. Our relationship is only here in Hong Kong. Back home, we will be just friends, or sisters even. We know that our relationship won't be accepted back home. We don't want to shame our parents. As long as we can have our relationship here in Hong Kong, we will go through with it." For Heberer (2017), this provisional state does not make the relationship false but rather 'troubles the moralizing narratives that separate 'authentic' and true' social worlds from undesirable forms of life" (p. 441) by showing alternative spaces and imaginaries of intimacy that exceed identitarian notions of queerness. This is just like what the shop owner of Abadi Store, a place where lesbian couples go to marry, asserts. In one of the interviews shown in the film, the owner of the store says: "Maybe this is unrecognized in other parts of the world. But this is a fact." (16:48-17:05 mins.). Rian's practice of intimacy produces not just a counter-image to the proper womanhood sanctioned by the state and global capital but also shows how space can be made to accommodate alternative forms of sociality and sexuality, no matter how ephemeral and transitory they may be.

In the short documentary's closing, we see a screen-split, with Ruwati riding a motorcycle driven by her fiancé in Indonesia on the left, and Rian riding a bicycle with her girlfriend on the right. This scene signifies a kind of mobility that, literally and figuratively, can only exist transnationally for migrant subjects. This mobility can only be managed through the reworking of conservative ideas of sexuality for Ruwati and the acceptance of the temporariness of affection and romance for Rian. And in both cases, the forging of intimacy to gain movement and freedom takes place in public spaces that mediate public discourses of belonging back home and abroad.

\section{Spaces for Everyday Resistance}

Intimacy for migrant women does not just come in the form of romance and sexual relationships. It can also be about kinship with other FDWs. The emotional bonds that are formed when congregating in public during their days off also make them more open to go out of themselves to help each other in times of crisis. As seen in Zoitl's (2007) Exchange Square, 
the everyday and the uneventful is an important idiom that documents the experiences of Filipina domestic workers during their days off at Central. Mundane scenes captured in the documentary expose the various social practices that Filipino women deploy to build and sustain their alternative communities every Sunday.

The migrant Filipinas' social gathering also reinscribes the urban geographies of their host city by the way they relate to private and public spaces. “Theresa's Room," one of Zoitl's vignettes, for example, portrays a day in the life of Maria Theresa Hamto, a Filipino domestic worker. The camera follows her, and the audience sees her daily routine: carrying groceries, commuting in a bus, and entering a condominium where she works and lives. Inside her employer's flat, while she is seen on the screen casually cleaning up her ward's bedroom before transferring to her much smaller room, viewers hear her voice-over stating how easy and kind her employer's family is to her, allowing her to cook her own food and do whatever she wants as long as she is done with her tasks. In the private realm of her workplace, Theresa seems to be a bit cautious and self-conscious, moving nimbly so as not to disturb her employer's child watching the TV or quietly rummaging through her things inside her cramped room. In the last minutes of this vignette, though, the scene shifts to another location. As Theresa goes to Chater Road, the camera captures how her face instantly brightens up as loud music and jovial calls from her fellow Filipina domestics greet her. Before the segment ends, Theresa is seen dancing with her friends on the open streets.

In this visual play of differential spaces, the audience gets to have a glimpse of how Theresa relates differently to her hosts' private and public spaces. She transforms from a diminutive maid inside her employer's house to a buoyant friend to her peers as she steps into Central. Socially isolated for most of the week in private households notwithstanding their employer's kind and considerate treatment, Chater Road becomes a liminal space where the public realm also functions as an intimate space where women like Theresa let their hair down among fellow domestics in a place they call "home away from home" (Peralta, 2004, p. 143).

Zoitl's approach of placing Theresa's life inside and outside the household continuously in a vignette reveals the "spatial division into public and private, while at the same time showing their mutual interpenetration" (Wohrer, 2008, p. 53). This visual strategy illustrates not just how Theresa's intimate and public selves are reconfigured by transnational migration but how her movements and disposition inside and outside the house are still linked to each other, mutually determining the way she acts and feels in various spaces. 
Zoitl's documentary series also shows the sundry activities that make up these public gatherings in Central. In the segment "Statue Square," she captures groups of Filipinas posing for a photographer, in front or beside the park's colourful decors. This seemingly uneventful scene is shot with the photographer outside the frame. Thus, it is as if the women are striking a pose for Zoitl's camera. Taking pictures of themselves with friends in Hong Kong's public spaces is a typical activity among migrant women in their days off. They document not only their time of enjoyment but also the emotional bonds they form with each other. Such seemingly mundane activities that include gossiping, eating together, and having their photographs taken can be seen as productive time in themselves. As Neferti Xina Tadiar (2009) argued, migrant domestic workers' periods of relaxation are also "time of recovery and restoration of (life) times lost in the production of time for others" (p. 91). More than this, they are forms of mutual exchanges that connect Filipina domestic workers to each other and turn casual acquaintances into deeper friendships.

These forms of group bonding are also highlighted in the many public performances, like singing and dancing, that not only disrupt their ordinary activities but also entice them to participate. Zoitl's "HSBC Bank Building," for example, presents the mass of Filipina women occupying the basement of HSBC Building, one of Central district's most prominent skyscrapers. The camera scans the vicinity, catching the hubbub of women gossiping, sleeping on floors, and reading romance pocketbooks, until it stops in front of a woman who suddenly stands, picks up a microphone, and sings. While still foregrounding the Filipina performer, the camera shows her fellow maids at the back, previously engaged in their little cliques now slowly taking notice of her. And on the last note of the song, everyone cheers and applauds.

Similar to this are Zoitl's "Babae/Woman," which shows Theresa reciting a narrative poem on the travails of domestic workers in Hong Kong in front of an appreciative audience; and "Next to Prada Store," which shows footages of Filipina domestics performing a traditional community dance from Northern Philippines. With improvised agung (hanging gongs) made from tin cans, the circle of Filipina maids dancing in the second video widens as more and more of their fellows join in. For casual observers, these creative interferences of bodily performances contribute to Hong Kong's display of diversity, disrupting both the predominant local Chinese culture of the city or the usual sea of business suits in Central's business districts. For the migrant Filipinas, however, they are also cultural expressions that articulate their experience as well as their social identity beyond their being FDWs. Performing in public does not only make Central District a space 
akin to their homeland but also serve as avenue for forming and performing their other subjectivities. As Ming-yan Lai (2010) observed, singing and dancing are ways in which Filipinas and Indonesians "assert their visibility" through spectacle, "resist their reduction to domestic bodies at the beck and call, or mercy, of their employers," and highlight their capacity of "enacting and assuming different subjectivities" by "drawing attention to their bodies as medium of volitional self-expression rather than just objects of victimization and exploitation" (pp. 505-506). Moreover, for Lai, "these performances celebrate the diversity of ethnic cultural origins, talents, and interests of the migrant domestic workers, even as they foster solidarity and community building among diverse constituencies" (p. 501). The range of activities that takes place in Central also serves as emotional outlet that fortify and recharges them for another week's grind. In these ways, Filipino migrant women construct forms of intimacies that range from fellowship, friendship, kinship, and even romantic affairs in public during their days off.

Exchange Square (Zoitl, 2007) documents this network of support groups as seen in the footages of socio-civic organizations that assist migrant women workers. A few minutes away from Chater Road area where most Filipina domestics congregate is Mission for Migrant Workers, one of the oldest migrant support group in Asia. One segment of the film focuses on the goings-on inside the office of this nonprofit organization, including how Filipina women like Theresa, many of them domestic workers themselves, volunteer as caseworkers and support point persons for fellow migrants in Hong Kong. They are shown offering advice to domestics who are facing problems with their contracts or are experiencing abuse from their employers.

In another segment, Zoitl documents the life inside Bethune House, a shelter for distressed FDWs located a few minutes away from Central. Inside the halfway house, dozens of Indonesians and Filipinas who had been unjustly terminated or have pending cases with their previous employers, share the available space and resources. They cook food for all occupants of the refuge house, clean their shared areas, eat together, and counsel each other, demonstrating how migrant women not only go beyond their own personal problems but also exceed their ethnic and racial identities to receive and reciprocate help in times of crisis.

Both of these video segments attest to how these women are not only dependent on the assistance and aid that the church and other socio-civic and nonprofit organizations extend to them, but are also helping themselves by mutually supporting each other's struggles. This sense of community is all the more emphasized when Filipino and Indonesian domestic workers participate in political demonstrations. In Zoitl's last vignette, "Snake 
Rally," is a scene showing Filipina domestics protesting against Hong Kong's levy in hiring foreign maids, which, during the time of filming, was still being implemented. In a series of long takes, Filipina workers are shown roaming the spaces of Central District starting from Chater Garden to the closed off area of Chater Road, and passing through the tunnels towards Central Harbour, chanting slogans, and holding placards. Then Indonesian domestic workers, who emerge from the MTR station, join them in chanting and calling for the abolition of the levy. This footage shows how the off-day practices have also become crucial in the emergence of political organization among migrant women because some of the Filipinas and Indonesians do not just gather in Central or Victoria Park to take respite from their isolated and long working week but also participate in discursive assemblies that push forward their claims to Hong Kong.

"The appropriation of these public spaces on Sundays," as Law observed, "is important because it enables more overt political forms of mobilisation" (2002a, p. 1638). The prominence of these political demonstrations interrupting the usual activities of FDWs' public gathering has a variety of discursive function for fellow migrant women and to their hosts as well. Because the rallies like the one documented by Zoitl usually go around the areas of Central and Victoria Park where there are high concentrations of FDWs, they also serve as awareness campaigns for non-participating domestics. As such, these protest actions could become seeds for other embodied expressions and avenues for FDW resistance.

For the locals and other "outsiders," these rallies help them see FDWs in another light: they are no longer just subjects of spectacle or symptoms of unequal power and economic relations in the global city but active political actors. The FDWs' political assemblies in Central and Causeway Bay infuse Hong Kong's public spaces with new meaning-one that is not just about it being the locus of the spectacle of migrant women but also "a densely political site where the politics of domestic work are brought to the public" (Law, p. 1630). In this sense, these spaces serve also as a platform where actual policies and discourses on migration and transnational domestic workers are debated and negotiated.

\section{Sites of Transgression}

In this paper, I offer a reading of two documentary films, Effort for Love (Susanti, 2008) and Exchange Square (Zoitl, 2007), to reveal how Filipino and Indonesian migrant women's everyday practices of intimacy and community-building in Hong Kong's public spaces generate alternative imaginaries for belonging. In my reading of Susanti's film, I posited that public space for Indonesian domestic workers becomes an arena where 
alternative forms of sexuality become possible and visible, while problematic narratives of womanhood get to be challenged and mediated. Through Rian and Ruwati, the documentary short exposes the complexity of intimacy. Deployed in public, it becomes a way of staking claim to one's right to belonging, though it all unsettles both the exclusionary and discriminatory policies of their host city-state and the problematic moral discourses of sexuality and citizenship of their home country.

In my analysis of Zoitl's (2007) documentary video series Exchange Square, I track how public intimacy is crucial in the social practice of Filipina domestic workers. This video series illuminates how forging social bonds through mundane activities during their days off is key to the emergence and continued vitality of political organizations of Filipina and Indonesian domestic workers. Their social practice of congregating at Central and Victoria Park during Sundays has brought about a huge network of cliques and support groups, which has become the grassroots organization for migrants (Hsia, 2010). Communities of Filipina domestics have merged with Indonesian migrant women and other ethnic minorities. This organizing work has led to the rise of transnational activism in Hong Kong. As a result, FDWs and their social practices in public, as Constable (2010) argued, do not only challenge and reconstruct the "domestic/public, private/political dichotomies" but also demonstrate how "the domestic transcends and transforms the public, political, transnational, and global" (p. 143).

Indeed, the embodied expressions of Southeast Asian migrant domestic workers seen in Susanti and Zoitl's works show the ways in which FDWs use intimacy in public to build social networks; find relief and comfort among friends, lovers, and fellow migrant workers; foster community; and forge solidarity. But this building of intimacy does not necessarily lead to social inclusion in their host state. After all, the very fact that they have to spend their rest day in a public space to fight for their right to love, reclaim their own bodies, find their own networks of support, and even protest, attests to how far Hong Kong's hospitality can only go. However, these FDW social practices still reflect openings and thresholds that could be actively examined and challenged, especially in a cosmopolitan city like Hong Kong. 


\section{References}

Aitken, S. C., \& Zonn, L. E. (1994). Place, power, situation, and spectacle: a geography of film. Lanham and London: Rowman \& Littlefield Publisher.

Amnesty International. (2013). Exploited for profit, failed by governments: Indonesian migrant domestic workers trafficked to Hong Kong. Retrieved from http://www.amnesty.org/en/library/asset/ ASA17/029/2013/en/d35a06be-7cd9-48a1-8ae1-49346c62ebd8/asa170292013en.pdf.

Bok, H. T. (2013). Sunday Girls. South China Morning Post. Retrieved from South China Morning Post website: http://www.scmp.com/magazines/post-magazine/article/1217312/sunday-girls.

Carvalho, R. (2019). Migrant domestic workers prop up Hong Kong's economy, so why are they excluded? South China Morning Post. Retrieved from South China Morning POst website: https://www.scmp. com/week-asia/economics/article/2188754/migrant-domestic-workers-prop-hong-kongseconomy-so-why-are-they.

Census and Statistics Department HK. (2014). Number of foreign domestic workers by nationality. Retrieved from http://www.statistics.gov.hk/pub/B10100032014AN14B0 100.pdf.

Cheung, K. (2017). How Hong Kong's developers are abusing public space. Retrieved from Hong Kong Free Press website: https://www.hongkongfp.com/2017/09/17/hong-kongs-developers-abusingpublic-space/.

Çinar, A., \& Bender, T. (2007). Urban imaginaries: Locating the modern city. Minnesota: University of Minnesota Press.

Constable, N. (1997). Maid to order in Hong Kong: Stories of Filipina workers. Ithaca: Cornell University Press.

Constable, N. (2010). Migrant workers and the many states of protests in Hong Kong. In N. Constable (Ed.), Migrant workers in Asia: Distant divides, intimate connections (pp. 127-144). London and New York: Routledge.

de Guzman, O. (2003). Overseas Filipino workers, labor circulation in Southeast Asia, and the (mis) management of overseas migration programs. Kyoto Review of Southeast Asia, (4). Retrieved from http://kyotoreview.cseas.kyoto-u.ac.jp/issue3/index.html .

Heberer, F.-M. (2017). Migrating intimacies: Media representations of same-sex love among migrant women in East Asia. Sexualities, 20(4), 428-445.

Hincks, J. (2017). In the world's most expensive city, 1 in 10 maids sleeps in a kitchen, toilet, or corner of the living room. Time Magazine. Retrieved from Time Magazine website: http://time.com/4775376/ hong-kong-migrant-workers-maids-helpers-conditions/.

Hsia, H.-C. (2010). The making of a transnational grassroots migrant movement: A case study of Hong Kong's Asian Migrants' Coordinating Body. In N. Constable (Ed.), Migrant workers in Asia: Distant divides, intimate connections (pp. 105-126). New York: Routledge.

International Organization for Migration. (2010). Labour migration from Indonesia: An overview of Indonesian migration to selected destinations in Asia and the Middle East, 9. Retrieved from https://www.iom.int/jahia/webdav/shared/shared/mainsite/published_docs/Final-LM-ReportEnglish.pdf.

Kwok, B. (2019). Hong Kong flats tiny but frighteningly expensive. Asia Times. Retrieved from Asia Times website: https://www.asiatimes.com/2019/02/article/hong-kong-flats-tiny-but-frighteninglyexpensive/. 
Lai, M.-y. (2010). Dancing to different tunes: Performance and activism among migrant domestic workers in Hong Kong. Women's Studies International Forum, 33(1), 501-511.

Law, L. (2001). Home cooking: Filipino women and geographies of the senses in Hong Kong. Ecumene, $8(3), 264-283$.

Law, L. (2002a). Defying disappearance: Cosmopolitan public spaces in Hong Kong. Urban Studies, 39(9), 1625-1645.

Law, L. (2002b). Sites of transnational activism: Filipino non-government organisations in Hong Kong. In B. S. A. Yeoh, Teo, Peggy and Huang, Shirlena (Ed.), Gender Politics in the Asia-Pacific Region (pp. 205-222). London and New York: Routledge.

Ma, R. (2006). Envoys to help maids navigate moral maze. South China Morning Post. Retrieved from South China Morning Post website: http://www.scmp.com/article/537081/envoys-help-maidsnavigate-moral-maze.

Mission for Migrant Workers. (2013). Live In policy increases female FDWs' vulnerability to various types of abuse. Retrieved from http://issuu.com/mfmw/docs/primer_live-in english/1?e=8079376/2254015.

Nurchayati, N. (2010). Foreign exchange heroes or family builders? The life histories of three Indonesian women migrant workers. (Unpublished MA Thesis), Ohio University.

Olivieri, D. (2016). Diasporic proximities: spaces of 'home' in European documentary. Transnational Cinemas, 7(2), 135-150.

Peralta, M. T. (2004). From where are you back home?: Ethnography of Filipina domestic workers spending Sundays at Statue Square. (PhD), University of Southern California, Ann Arbor: UMI.

Pernin, J. (2010). Filming space/mapping reality in Chinese independent documentary films. China Perspectives, 2010(1), 22-34.

Remo, M. (2013). Remittances hit all-time high in 2012. Philippine Daily Inquirer. Retrieved from http:// business.inquirer.net/107845/remittances-hit-all-time-high-in-2012.

Rony, F. T. (2012). Transforming documentary: Indonesian women and sexuality in the film Pertaruhan [At Stake] (2008). In Y. Kim (Ed.), Women and Media in Asia: The Precarious Self (pp. 159-176). Basingstroke: Palgrave McMillan.

Sahin, Z. (2017). Hong Kong's struggle with space. Retrieved from TRT World website: https://www. trtworld.com/asia/hong-kong-s-struggle-with-space-9018.

$\mathrm{Sim}, \mathrm{A}$. (2009). The sexual economy of desire: Girlfriends, boyfriends and babies among Indonesian women migrants in Hong Kong. Retrieved from http://r4d.dfid.gov.uk/PDF/Outputs/WomenEmpMus/ Sim_Sexual_Economy_of_Desire.pdf.

Siu, J. (2018). Why foreign domestic workers in Hong Kong must leave in their employers' homes. South China Morning Post. Retrieved from South China Morning Post website: https://www.scmp.com/ news/hong-kong/community/article/2133377/why-hong-kong-wants-foreign-domestic-helperslive-their.

Siu, J., \& Lau, C. (2018). Judge quashes domestic helper's bid for change to 'ive-in' rule in Hong KOng. South China Morning Post. Retrieved from South China Morning Post website: https://www.scmp. com/news/hong-kong/economy/article/2133296/judge-quashes-domestic-workers-bid-changelive-out-rule-hong. 
Susanti, A. E. (Writer) \& A. E. Susanti (Director). (2008). Effort for Love ('Mengusahakan Cinta'), At Stake ('Pertaruhan'). Indonesia: Kalyana Shira Films.

Tadiar, N. (2009). Things fall away: Philippine historical experience and the makings of globalization. Durham and London: Duke University Press.

Ueno, K. (2013). Love gain: The transformation of intimacy among foreign domestic workers in Singapore. SOJOURN: Journal of Social Issues in Southeast Asia, 28(1), 36-63.

Wohrer, R. (2008). No room of one's own. In M. Zoitl (Ed.), Exchange Square: Activism and everyday life of foreign domestic workers in Hong Kong (pp. 50-57, 53). Berlin: Jovis Verlag.

Yeoh, B. S. A. (2004). Cosmopolitanism and its exclusions in Singapore. Urban Studies, 44(12), 2431-2445.

Yeoh, B. S. A., \& Huang, S. (1998). Negotiating public space: Strategies and styles of migrant female domestic workers in Singapore. Urban Studies, 35(3), 583-602, 598.

Zoitl, M. (Writer) \& M. Zoitl (Director). (2007). Exchange Square. In M. Zoitl (Producer), Chat(t)er Gardens: Stories by and about Filipino Domestic Workers (installation art and video series). Hong Kong and Berlin: Moira Zoitl.

\section{Note}

* The author wants to thank University Research Coordinating Office (URCO) of De La Salle University (DLSU) for the New PhD Grant that funded this article.

CARLOS M. PIOCOS III is an associate professor at Literature Department and a research fellow at Southeast Asian Research Center and Hub (SEARCH) of De La Salle University. He earned his PhD in Comparative Literature degree at the University of Hong Kong. His main research interests are cultural studies, Southeast Asian literature and film, migration and diaspora studies and affect studies. (Corresponding author: carlos.piocos@dlsu.edu.ph) 